\title{
In-cell Re-fabrication and Loss-of-coolant Accident (LOCA) Testing of High Burnup Commercial Spent Fuel
}

\section{Nuclear Technology}

Research and Development
A. Raftery
Y. Yan
T. Smith
Z. Burns
K. Terrani
K. Linton

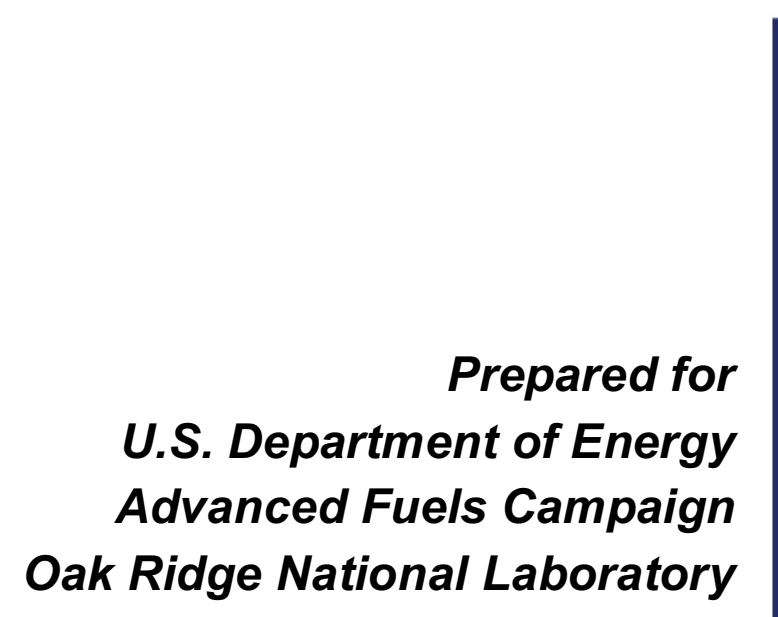





\section{DISCLAIMER}

This information was prepared as an account of work sponsored by an agency of the U.S. Government. Neither the U.S. Government nor any agency thereof, nor any of their employees, makes any warranty,

expressed or implied, or assumes any legal liability or responsibility for the accuracy, completeness, or usefulness, of any information, apparatus, product, or process disclosed, or represents that its use would not infringe privately owned rights. References herein to any specific commercial product, process, or service by trade name, trade mark, manufacturer, or otherwise, does not necessarily constitute or imply its endorsement, recommendation, or favoring by the U.S. Government or any agency thereof. The views and opinions of authors expressed herein do not necessarily state or reflect those of the U.S. Government or any agency thereof. 



\title{
In-cell Re-fabrication and Loss-of-coolant Accident (LOCA) Testing of High Burnup Commercial Spent Fuel
}

\author{
A. Raftery \\ Y. Yan \\ T. Smith \\ Z. Burns \\ K. Terrani \\ K. Linton
}

June 28, 2018

Prepared by

OAK RIDGE NATIONAL LABORATORY

Oak Ridge, TN 37831-6283

managed by

UT-BATTELLE, LLC

for the

US DEPARTMENT OF ENERGY

under contract DE-AC05-00OR22725 
In-cell Re-fabrication and Loss-of-coolant Accident (LOCA)

Testing of High Burnup Commercial Spent Fuel

This page is intentionally left blank. 


\section{SUMMARY}

A high burnup commercial spent fuel segment was re-fabricated into a pressurized test train for fuel safety testing in the Irradiated Fuels and Examination Laboratory (IFEL) hot cell facility at Oak Ridge National Laboratory. Descriptions of the in-cell re-fabrication capabilities and assembly of the loss-ofcoolant-accident (LOCA) test train are provided. An in-cell integral LOCA test was performed in the Severe Accident Test Station (SATS) by subjecting the fuel segment to a steam environment, internal pressure, temperatures up to $1200^{\circ} \mathrm{C}$, and water quench. The successful in-cell re-fabrication and integral LOCA demonstration test restores a domestic capability for out-of-pile integral fuel safety testing. In addition, this work establishes the SATS system as a vital tool for evaluation of commercial spent fuel and future accident tolerant fuel (ATF) concepts subject to design basis accident (DBA) and beyond design basis accident (BDBA) scenarios. 
In-cell Re-fabrication and Loss-of-coolant Accident (LOCA)

Testing of High Burnup Commercial Spent Fuel

This page is intentionally left blank. 


\section{CONTENTS}

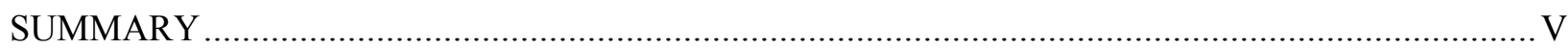

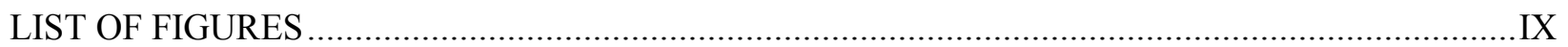

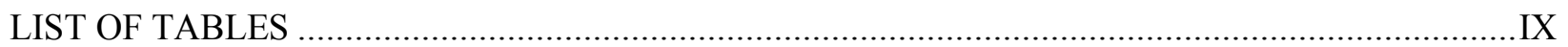

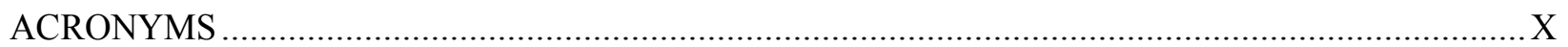

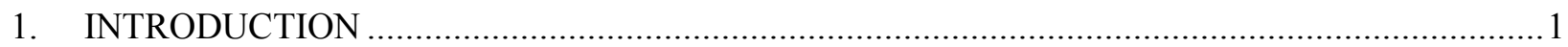

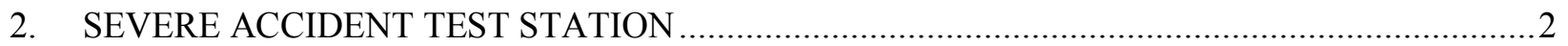

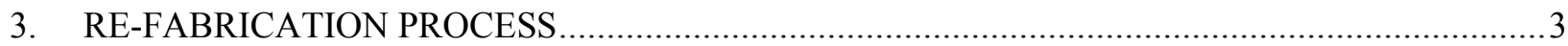

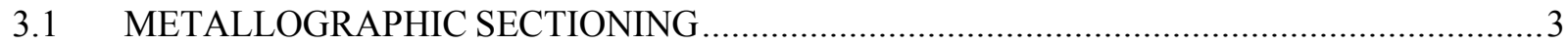

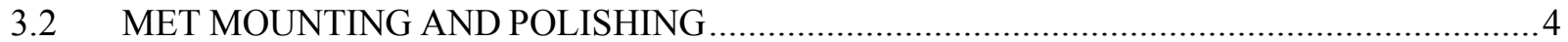

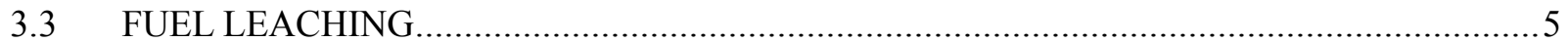

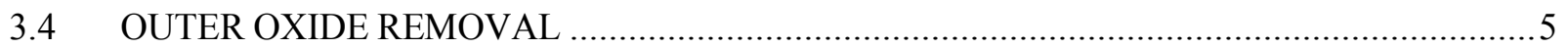

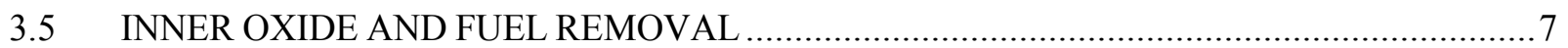

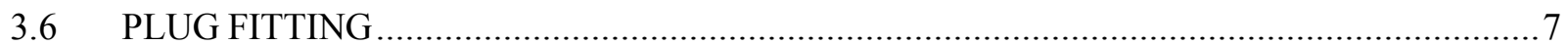

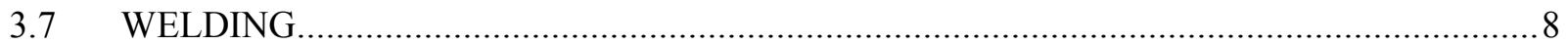

4. HIGH BURNUP FUEL ROD LOCA DEMONSTRATION …................................................. 9

4.1 ROD CHARACTERIZATION AND RE-FABRICATION …...........................................

4.2 INTEGRAL LOCA TEST ON HIGH BURNUP FUEL SEGMENT …................................ 10

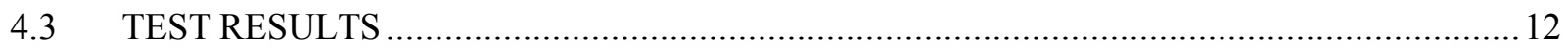

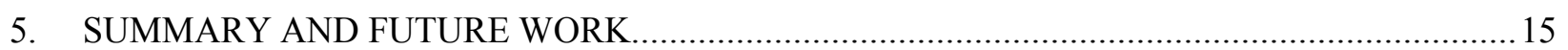

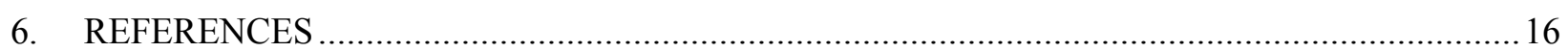


In-cell Re-fabrication and Loss-of-coolant Accident (LOCA)

Testing of High Burnup Commercial Spent Fuel

This page is intentionally left blank. 


\section{LIST OF FIGURES}

Figure 1. The Severe Accident Test Station pictured before it was placed in-cell at the IFEL. The test station includes the integral LOCA testing module (blue outline) and the BDBA high temperature furnace test apparatus (red outline) [9].

Figure 2. MET sectioning of a spent fuel rod on a low speed diamond saw.

Figure 3. MET mount cross section of North Anna fuel rod used to determine thickness of inner and outer oxide layer for reaming and plug fitting.

Figure 4. Fuel leaching assembly used to remove fuel from the end of the segment. ..............................5

Figure 5. Assembly used for lathe removal of the oxide layers. ..................................................... 6

Figure 6. Fuel rod segment shown (a) before and (b) after outer oxide removal. ..................................6

Figure 7. Fuel segment with the inner oxide removed after reaming. .............................................. 7

Figure 8. Schematic of end plug fittings showing (a) the entire fuel segment and (b) only the end plug section.....

Figure 9. Polysoude Orbital welder used to weld fuel segments end plugs prior to fuel safety testing (pictured out-of-cell)

Figure 10. Gamma count on high burnup PWR fuel rod, showing that the burnup is relatively stable between spacers [11].

Figure 11. Schematic of a 12" North Anna fuel rod (P16) segment, showing the segment (650D2) that was sectioned and used in the integral LOCA test.

Figure 12. North Anna fuel segment loaded in SATS LOCA test apparatus

Figure 13. Photographs taken during the in-cell LOCA test showing (a) the temperature ramp and

(b) immediately following the water quench

Figure 14. Temperature and pressure histories for the in-cell LOCA test NA\#1 through full LOCA integral test sequence, including water quench at $800^{\circ} \mathrm{C}$.

Figure 15. Manipulator holding the burst North Anna \#1 fuel rod segment in front of the SATS system after the completion of an in-cell LOCA test.

\section{LIST OF TABLES}

Table 1. Comparison of the ORNL in-cell LOCA integral test on the North Anna fuel segment with a previous test performed at ANL on a high-burnup specimen [12]. 


\section{ACRONYMS}

$\begin{array}{ll}\text { LOCA } & \text { Loss-of-coolant Accident } \\ \text { NRC } & \text { Nuclear Regulatory Commission } \\ \text { DBA } & \text { Design-basis Accidents } \\ \text { BDBA } & \text { Beyond Design-basis Accidents } \\ \text { ANL } & \text { Argonne National Laboratory } \\ \text { SATS } & \text { Severe Accident Testing Station } \\ \text { ORNL } & \text { Oak Ridge National Laboratory } \\ \text { ATF } & \text { Accident Tolerant Fuel } \\ \text { IFEL } & \text { Irradiated Fuels Examination Laboratory } \\ \text { MET } & \text { Metallographic } \\ \text { SEM } & \text { Scanning Electron Microscope } \\ \text { PWR } & \text { Pressurized Water Reactor } \\ \text { NA } & \text { North Anna } \\ \text { ATR } & \text { Advanced Test Reactor } \\ \text { INL } & \text { Idaho National Laboratory } \\ \text { TREAT } & \text { Transient Reactor Test Facility }\end{array}$


This page is intentionally left blank. 
In-cell Re-fabrication and Loss-of-coolant Accident (LOCA)

Testing of High Burnup Commercial Spent Fuel

This page is intentionally left blank. 


\section{IN-CELL RE-FABRICATION AND LOSS-OF-COOLANT ACCIDENT (LOCA) TESTING OF HIGH BURNUP COMMERCIAL SPENT FUEL}

\section{INTRODUCTION}

The requirements for nuclear fuel performance during various accident scenarios, including a loss-ofcoolant accident (LOCA), are defined in regulations set by the United States Nuclear Regulatory Commission (NRC) [1]. These regulations define the acceptable temperatures, oxidation, geometrical variations, and long-term cooling conditions that must be met by the fuel and cladding system in accident scenarios in order to license a reactor design. Accident scenarios are categorized as either design basis accidents (DBA), which are accidents the power plant systems have been designed to withstand, or beyond design basis accidents (BDBA), which are accidents that exceed the design scope of the plant [2]. Fuel safety testing systems are the primary mechanism used to evaluate fuel and cladding performance during accident conditions and assure compliance with NRC regulations.

Fuel safety test systems can isolate the separate effects of the accident (high temperature, steam, water quench) or be fully integral by including multiple phenomena expected to occur. The focus of safety testing is on evaluating the integrity of the cladding, which is the first barrier to the release of fission products during a nuclear accident. The need for testing irradiated fuel and cladding has increased due to improved knowledge that fuel characteristics are dependent upon burnup conditions. The entire fuel system undergoes changes during irradiation due to fission events and damage cascades created within the materials, meaning the behavior during an accident is dependent upon the current state of the irradiated materials. In addition, corrosion from long term water contact on the cladding creates degradation and weakening [3]. Nuclear fuel is now operating for a longer period of time than ever before; the maximum fuel burnup has increased substantially over the years to extract more energy and increase the efficiency of operating reactors [4]. Therefore, safety testing of commercial spent fuel over a range of burnup conditions will provide valuable data to understand safety margins over the entire fuel lifetime. In addition, out-of-pile integral LOCA tests provide a consistent basis to effectively separate the thermal and mechanical behavior during an accident from the behavior due to radiation and nuclear heating in a reactor environment. Both integral and separate effects LOCA tests are vital for the validation of advanced modeling and simulation tools for nuclear fuel behavior (e.g. BISON) and are a cost-effective screening tool for the more expensive in-pile tests.

There are a limited number of dedicated systems around the world capable of performing integral testing of irradiated nuclear fuel rods subject to DBA and BDBA scenarios [5]. The Integral LOCA Test System at Argonne National Laboratory (ANL) in the United States was used to test irradiated commercial nuclear fuel rods subjected to DBA scenarios until 2004. The only facilities that currently have operating integral fuel safety test systems capable of testing high burnup fuel are Studsvik (Sweden) and Halden (Norway) [6,7]. The objective in designing the Severe Accident Testing System (SATS) at Oak Ridge National Laboratory (ORNL) was to replicate the Integral LOCA Test System capabilities while optimizing and expanding the test conditions to include BDBA scenarios for commercial fuel. The SATS system is also intended to be utilized for out-of-pile safety testing of novel Accident Tolerant Fuel (ATF) and cladding response to DBA and BDBA scenarios. 
This report defines the process established for the in-cell re-fabrication of commercial spent fuel rods and summarizes the re-fabrication and LOCA testing of a high burnup fuel rod segment from the North Anna Nuclear Generating Station. The successful demonstration of fuel re-fabrication and LOCA testing in SATS has restored and enhanced the domestic capability for integral fuel safety testing of high burnup commercial fuel in the United States.

\section{SEVERE ACCIDENT TEST STATION}

The Severe Accident Test Station (SATS) is an in-cell test station located at the Irradiated Fuels Examination Facility (IFEL) at ORNL that is capable of testing nuclear fuel rods subjected to a range of accident scenarios. The capabilities of the test rig include exposing a fuel rod segment to conditions typical of DBA and BDBA scenarios. The specifics of the SATS design have been extensively covered in previous ORNL reports [8,9]. The test rig consists of two modules: one for integral testing of LOCA scenarios and one module with a high temperature furnace for testing of fuel segments subjected to BDBA scenarios (Figure 1).

The integral LOCA module has the ability to test a fuel rod segment up to $300 \mathrm{~mm}$ in length inside of an infrared furnace that reaches $1200^{\circ} \mathrm{C}$. The internal pressure of the rod can be set up to $8 \mathrm{MPa}(1160 \mathrm{psi})$ before the start of the experiment. Water quench is provided from a water reservoir. After the quench valve is opened, the test train quartz tube is filled as the water level rises from a supply line located at the bottom of the test train. The LOCA system can also test high temperature oxidation and quench of defueled cladding by using a pressure-less configuration. These tests evaluate the oxidation behavior and oxide morphology of the cladding material during accident scenarios.

The BDBA module contains a high temperature furnace $\left(>1600^{\circ} \mathrm{C}\right)$ and is capable of testing small fuel rod segments $(<50 \mathrm{~mm})$ exposed to extreme conditions. The samples hang from a high-purity alumina holder inside the furnace and a high temperature steam/gas mixture flows upward through the furnace and over the sample during the test.

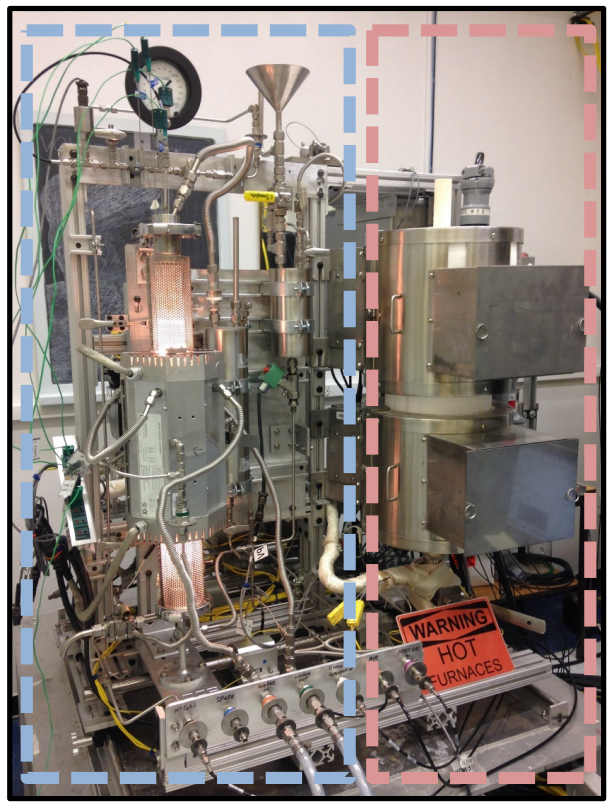

Figure 1. The Severe Accident Test Station pictured before it was placed in-cell at the IFEL. The test station includes the integral LOCA testing module (blue outline) and the BDBA high temperature furnace test apparatus (red outline) [9]. 


\section{RE-FABRICATION PROCESS}

The ability to test irradiated fuel requires that the fuel rod be re-fabricated from its current state into a fuel segment test condition. The entire re-fabrication process is completed in-cell at the Irradiated Fuels Examination Facility at ORNL. The steps during re-fabrication include metallographic sectioning, met mounting, fuel leaching, oxide removal, plug fitting, and welding. The result is a fuel segment that can be tested in the SATS system.

\subsection{METALLOGRAPHIC SECTIONING}

The first step of the re-fabrication process is sectioning the fuel rod and creating metallography (MET) mounts of the fuel cross-section immediately adjacent to the upper and lower portion of the planned test segment. The mounts are used to determine the oxide layer thickness on the inner and outer diameter of the cladding. In a later step, the oxide layers and fuel are removed from the weld region of the test sample to ensure a tight end-plug fitting against the metal cladding.

To perform this step, fuel rods are loaded into the v-block of a slow speed diamond saw and the sample is secured by tightening the wing nuts. A MET slice of 0.1 " length is obtained by setting the edge of the fuel rod at the edge of the blade and adjusting the barrel micrometer two clockwise rotations, shown in Figure 2. The saw speed is regulated by a Variac controller in which a $30-40 \%$ power setting ensures a smooth cutting process. Specimen cut times range from 10-45 minutes depending on the cladding material, cladding dimensions, and fuel conditions. Once the MET segment finishes the cutting process, it drops into the saw coolant water tray and is retrieved out of the bottom mesh trough using manipulators. The segment is then transferred to its designated storage container and transported to the Scanning Electron Microscope (SEM) hot cell for mounting and polishing.

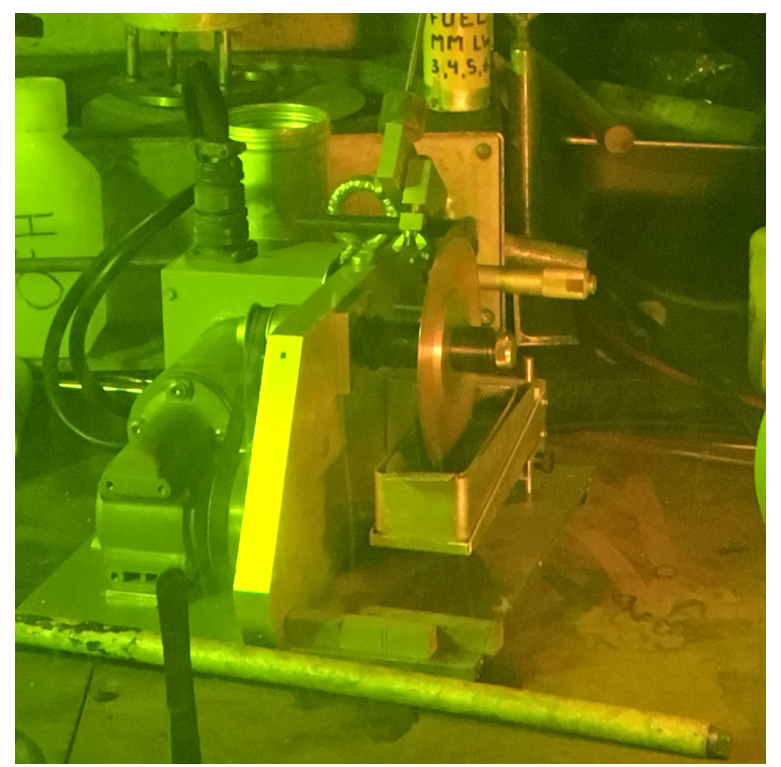

Figure 2. MET sectioning of a spent fuel rod on a low speed diamond saw. 


\subsection{MET MOUNTING AND POLISHING}

Due to differences in size, aluminum mounting fixtures are machined to custom fit each MET segment. The LOCA fuel segments require a mount with an inner diameter greater than 0.375 " to accommodate the entire sample. These mounts are scribed with a unique mount number and loaded into the cell by facility personnel. A 7.5:1 resin to hardener ratio epoxy is used to secure specimens in the mounts. This mixture is mixed outside the hot cell and poured into a small vile for loading into the hot cell. Once inside the SEM cell, the epoxy is applied to the bottom of the aluminum mount and the specimen is placed in the desired orientation. The sample is then fully submerged as more epoxy is applied over it, after which it is allowed to cure for 24 hours.

Once the curing process is complete, the mount is placed into the MiniMET polisher and is ground down to the cladding surface using a $30 \mu \mathrm{m}$ polishing pad. A $15 \mu \mathrm{m}$ pad is then used to remove any excess epoxy from the top of the mount and ensure flatness so that polishing can begin from a smooth surface. The specimen is polished with Isocut fluid and a series of polishing pads $(9 \mu \mathrm{m} \rightarrow 6 \mu \mathrm{m} \rightarrow 3 \mu \mathrm{m} \rightarrow 1 \mu \mathrm{m} \rightarrow$ $0.5 \mu \mathrm{m} \rightarrow 0.1 \mu \mathrm{m})$. In some cases, fuel may break out of the specimen and scratch the specimen, requiring an additional "back potting" step to prevent further fragmentation. To back pot, epoxy is applied to the top of the specimen and a vacuum is pulled on the entire piece, pulling the epoxy down into any void space. The epoxy is then cured, and the process follows as before.

After the polishing steps are complete and the specimen is cleaned with isopropyl alcohol, multiple images of the MET specimen are taken. The oxide layer is measured in various locations on each image in order to find an average on both the inside and outside of the fuel cladding (Figure 3 ). These measurements are used later to inform the oxide removal step.

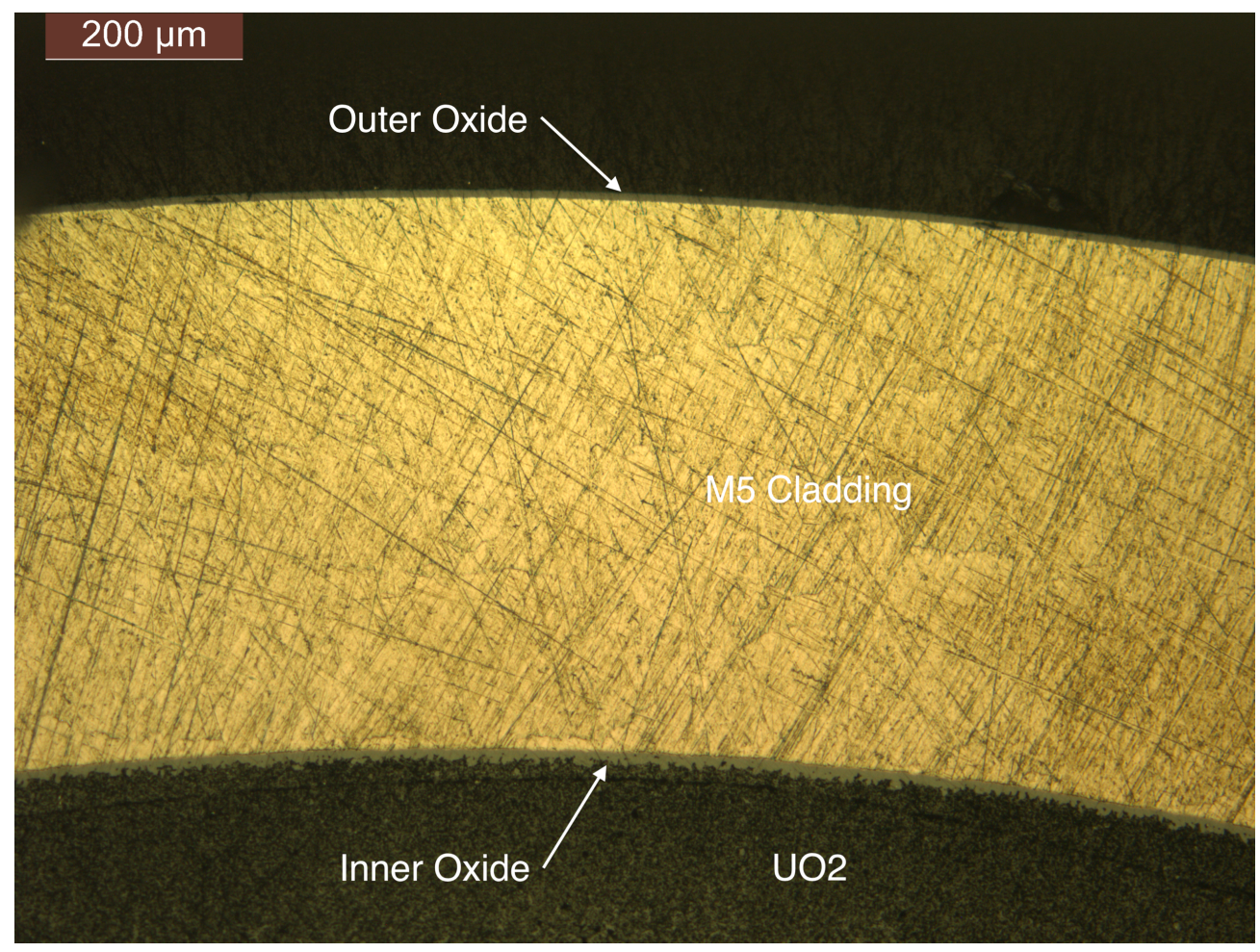

Figure 3. MET mount cross section of North Anna fuel rod used to determine thickness of inner and outer oxide layer for reaming and plug fitting. 


\subsection{FUEL LEACHING}

Approximately 0.5 " of fuel is removed from the end of each fuel segment in order to provide room for the end plugs to fit securely on the segment prior to welding. The LOCA fuel rod is placed vertically into a $250 \mathrm{~mL}$ beaker and filled with $\sim 100 \mathrm{~mL}$ of nitric acid to cover the bottom half inch of the fuel segment. This beaker is then placed into a steel pan on top of a hot plate to ensure that no fuel or acid is spilled on the work surface, and the hot plate is turned on to a medium heat level of 4.2, as shown in Figure 4. The leaching process is left to proceed for 1.5 hours at just below the boiling point of the acid bath. Once completed (both ends), the fuel segment is taken out of the beaker and the fuel leach result is measured to ensure completion to the proper depth. The waste liquid is poured into the designated bottle and the fuel rod is transported to the lathe for oxide removal.

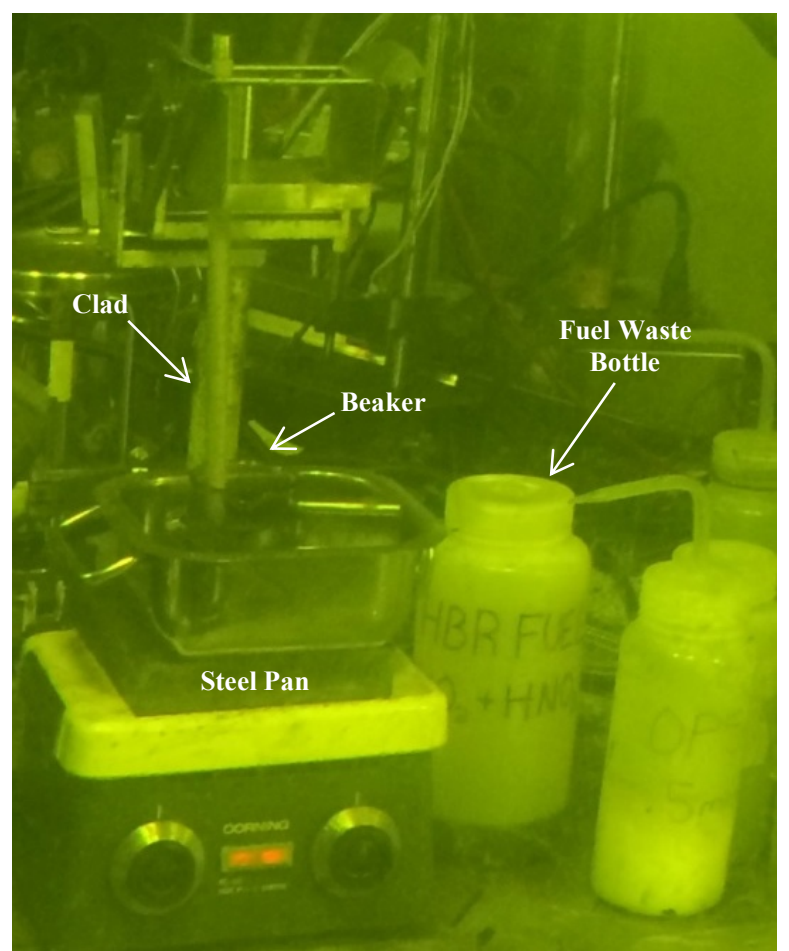

Figure 4. Fuel leaching assembly used to remove fuel from the end of the segment.

\subsection{OUTER OXIDE REMOVAL}

The LOCA fuel rod outer diameter oxide is removed from each end of the fuel rod using the program designed oxide/fuel removal lathe. The amount of oxide to be removed is directly measured from the MET mount pictures to ensure accuracy. To begin the removal process, the fuel rod is inserted into the chuck and secured by the tightening pins, as indicated in Figure 5. The diamond file is primed with a steel brush before each removal to ensure an even removal of oxide. Once the file is primed, the file is placed into the ready position and aligned on top of and flush to the right end of the rod using the left to right alignment wheel shown in Figure 5. To center the diamond file, the left to right alignment wheel is rotated 1 full counter clockwise rotation. The front alignment wheel is aligned so that the tip of the diamond file is in line with the rod. The motor is turned on at $3 / 4$ speed to initiate cladding rotation, which starts the removal process. The front alignment wheel is rotated a full rotation every minute until completion. Figure 6 shows a segment before and after the outer oxide removal. Diamond file priming is performed intermittently to ensure an even removal. 

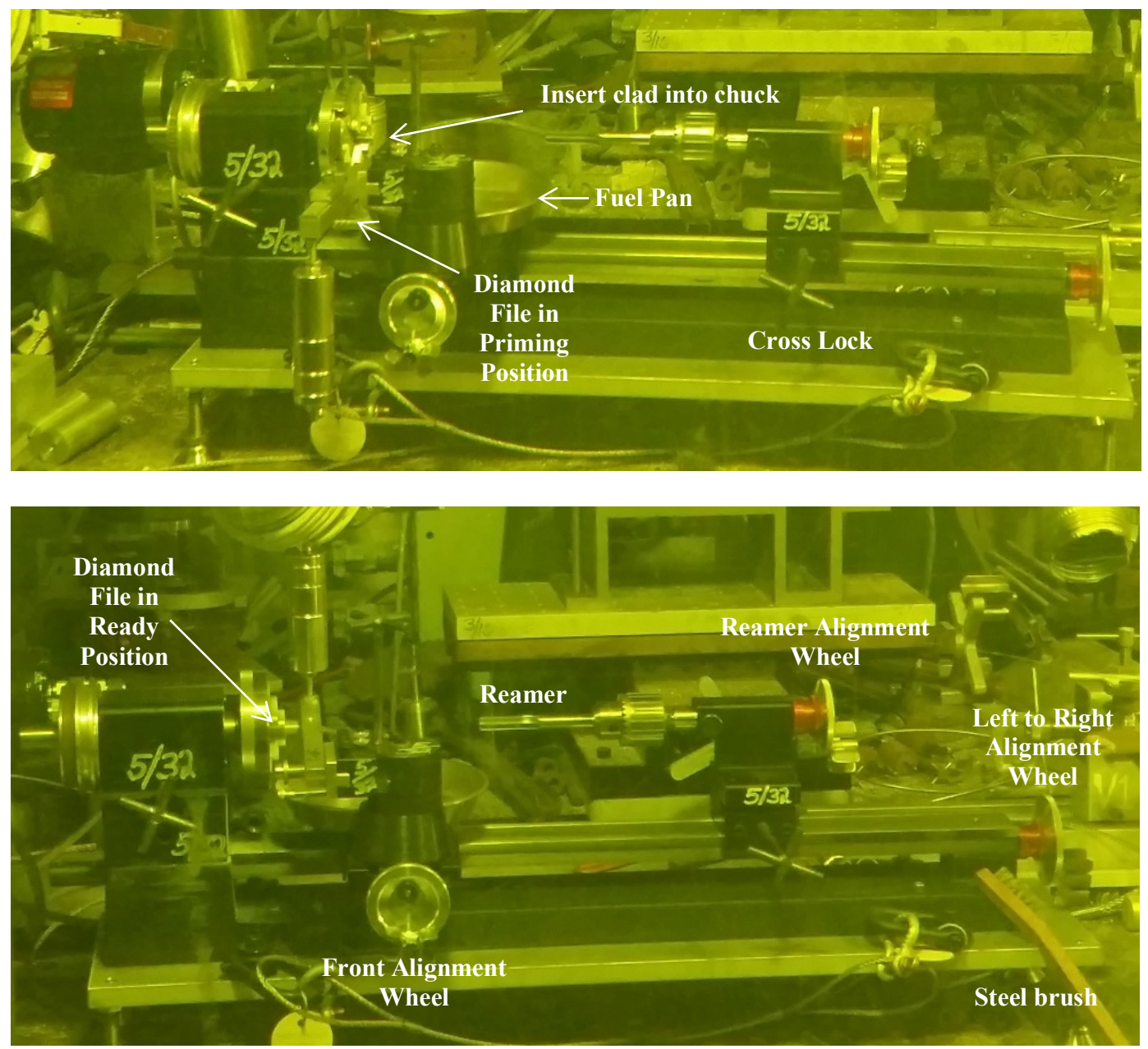

Figure 5. Assembly used for lathe removal of the oxide layers.

(a)

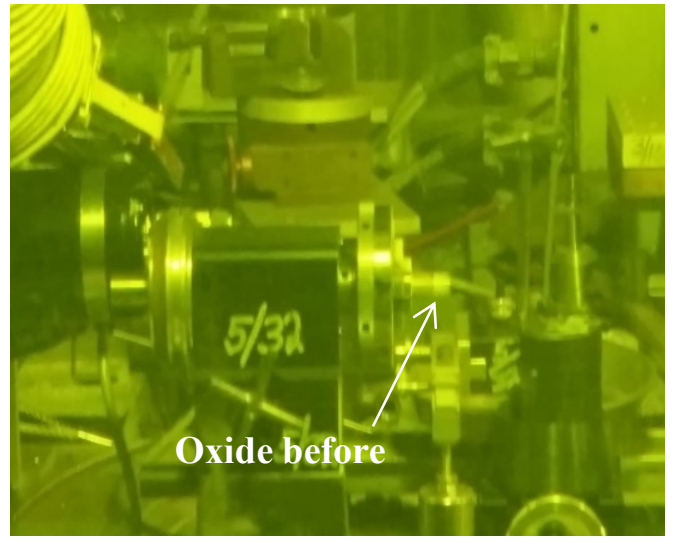

(b)

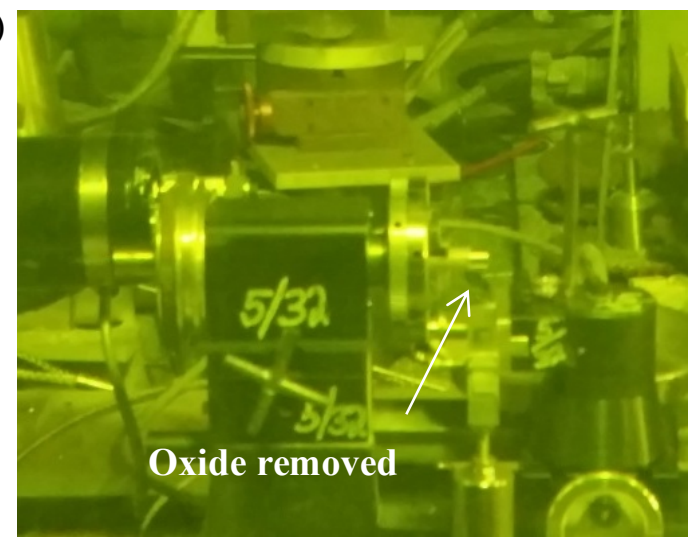

Figure 6. Fuel rod segment shown (a) before and (b) after outer oxide removal. 


\subsection{INNER OXIDE AND FUEL REMOVAL}

It is very important that little metal is removed from the fuel rod during the inner diameter sizing and reaming so that the welding will be successful. For this reason, a customized reamer size is calculated from the MET mount micrograph and mounted onto the lathe. The reamer is positioned just outside the clad opening and the cross lock is tightened to ensure that the reamer is straight, and the motor is turned on to $1 / 4$ speed. The reamer is slowly inserted into the fuel segment by rotating the reamer alignment wheel clockwise for approximately 10 rotations for a $1 / 2$ " removal, shown in Figure 7.

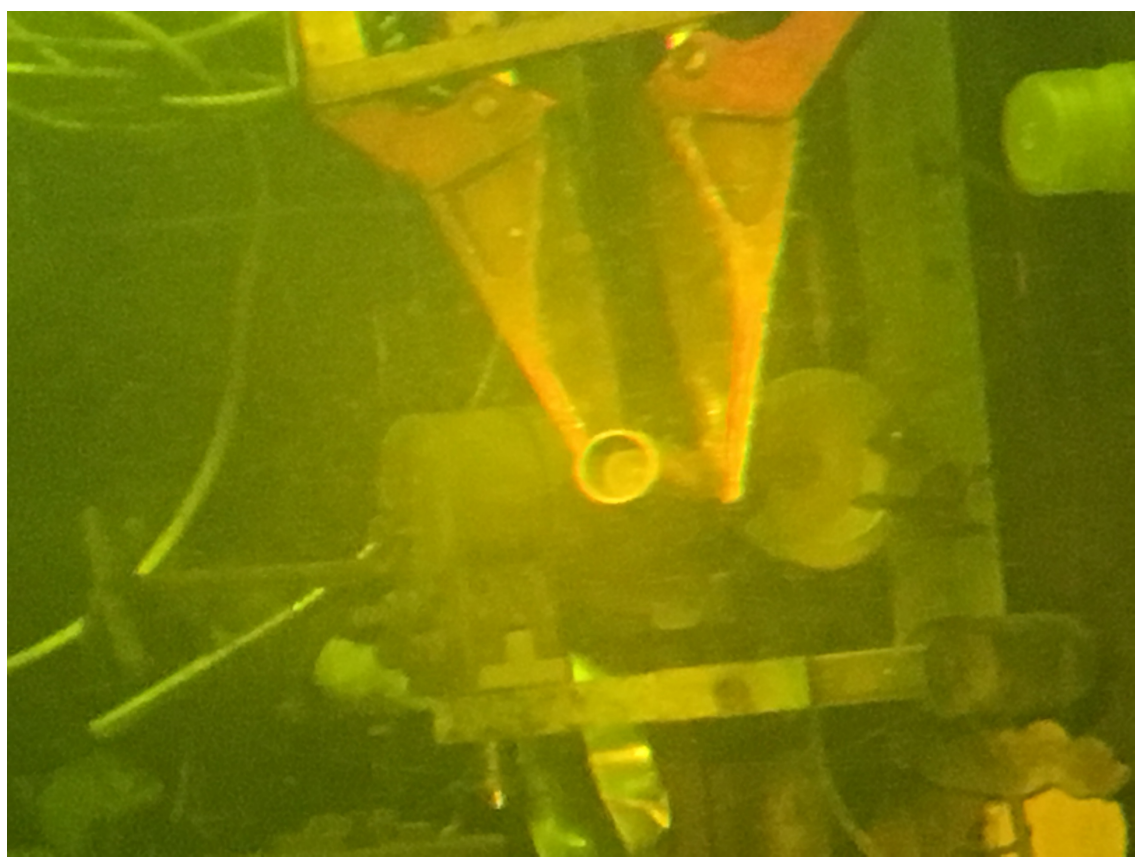

Figure 7. Fuel segment with the inner oxide removed after reaming.

Once the oxide/fuel removal is complete, a flare reamer is installed in place of the inner diameter reamer to lightly remove oxide and any burs accumulated during sectioning on the cut surface of the rod. The flare reamer has the same procedural set up as the inner diameter reamer. Using a motor speed of $1 / 4$, the flare reamer is rotated until it comes in contact with the fuel rod using the reamer alignment wheel for approximately 1 second.

\subsection{PLUG FITTING}

Each end of the fuel segment requires a customized end plug, which is welded to the cladding to seal the fuel segment. The end plug material is therefore selected based on the fuel system. To confirm the inner diameter dimensions, an appropriate plug gauge standard size is chosen by using the calculations from the MET micrograph. Once the standard is loaded into the hot cell, it is inserted into the end of the fuel rod and tested for snugness. The appropriate dimensions are then used for fabrication of the actual plugs, and the newly fabricated plugs are inserted into the end of the fuel rod by carefully tapping each end plug until it is flush with the cladding end. The flat end plug is inserted first (before inserting the upper gas end plug) to ensure the gas end plug is not damaged during installation of the flat end. A schematic of the end plug fittings is illustrated in Figure 8. 
(a)

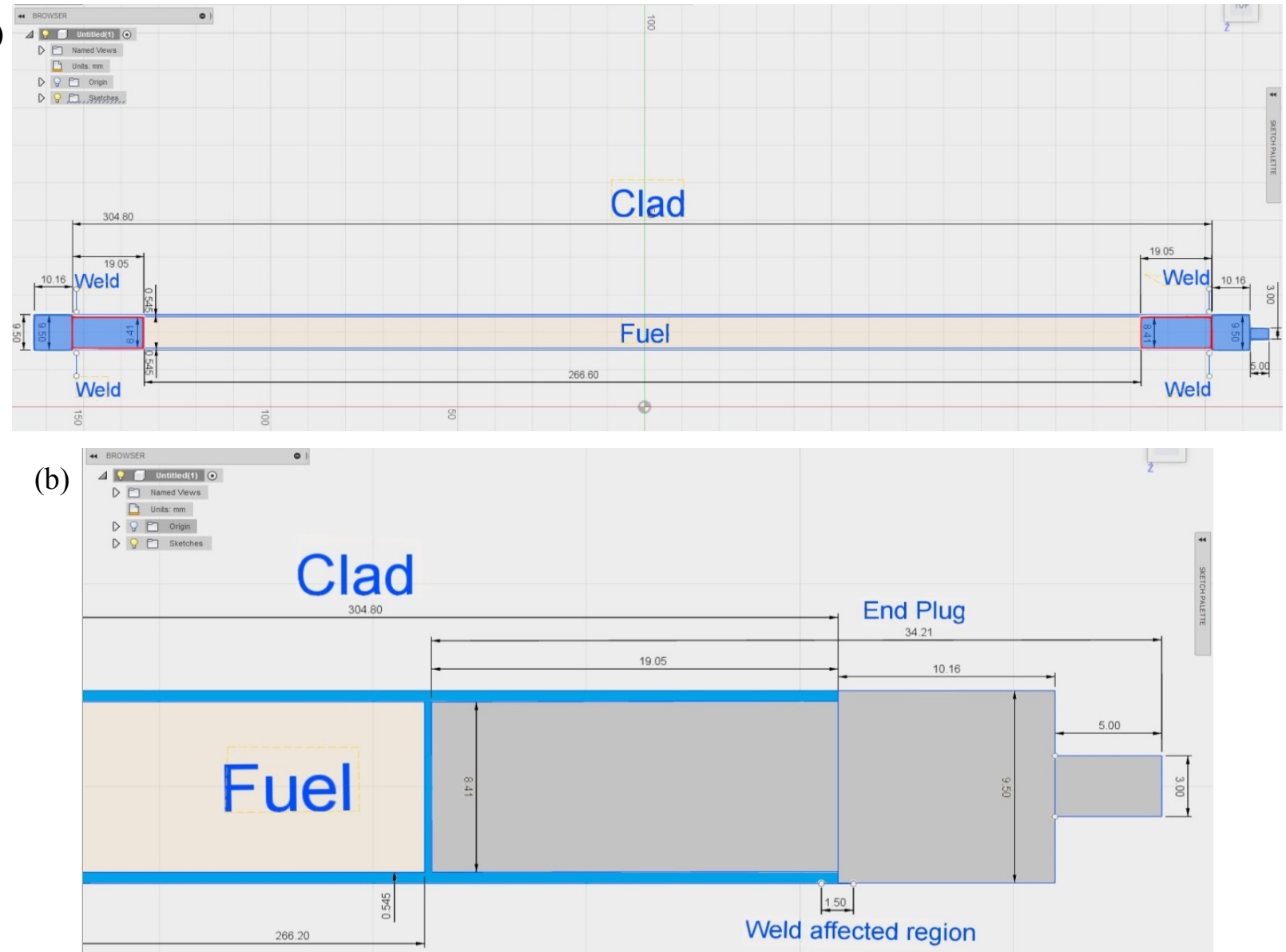

Figure 8. Schematic of end plug fittings showing (a) the entire fuel segment and (b) only the end plug section.

\subsection{WELDING}

An in-cell Polysoude Orbital Welder is used to weld each end plug to the cladding wall (Figure 9). Prior to in-cell welding, a customized welding program is optimized out of cell through practice on samples made of the same materials and with similar dimensions. Once the fuel rod is fit with the appropriate sized plugs, it is placed into the sample holder and clamped down. The weld line is aligned using the appropriate spacer, which is determined by which end of the plug is being welded. There is a custom welding program dedicated for automated welding of spent fuel rods. The welder is accompanied by a 20 psi argon pressure flowing continuously over the section being welded. Once the welding program is complete, the electrode is moved to the starting position and the fuel rod can be positioned for the next weld. 


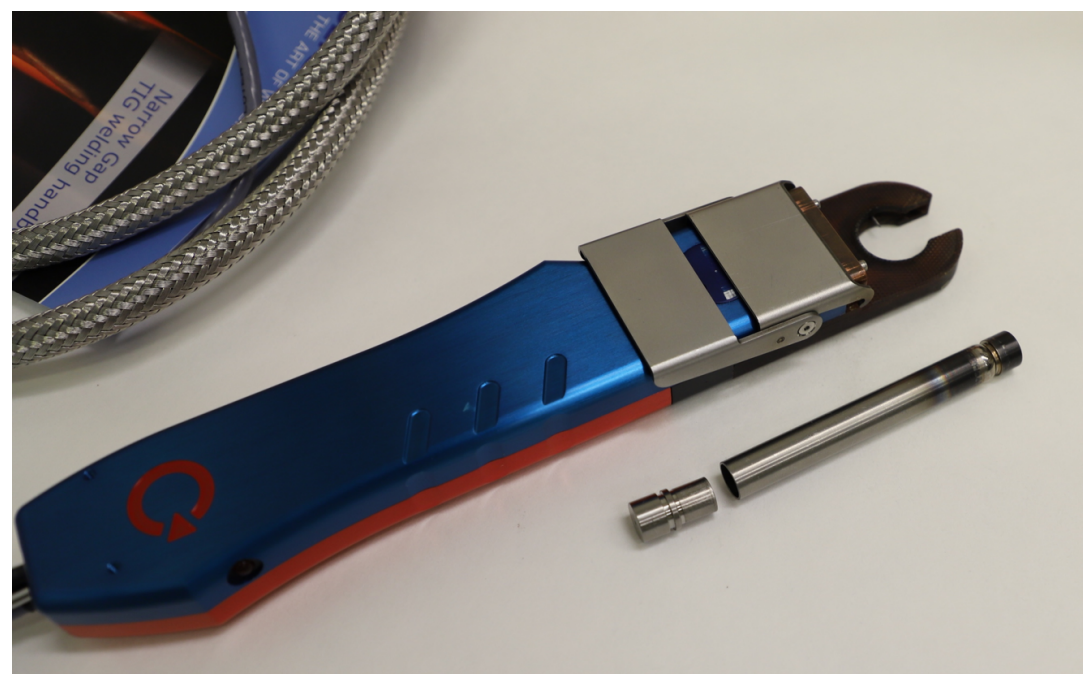

Figure 9. Polysoude Orbital welder used to weld fuel segments end plugs prior to fuel safety testing (pictured out-of-cell).

\section{HIGH BURNUP FUEL ROD LOCA DEMONSTRATION}

During the development and benchmarking of the in-cell Severe Accident Test Station, numerous out-ofcell LOCA tests were conducted with unirradiated 17x17 Zircaloy-4, which was filled with zirconia pellets to simulate the heat capacity of the fuel. After the SATS was installed in the main hot cell in 2017, a full sequence in-cell LOCA test was conducted with the unirradiated Zry-4, the results of which were reported in a previous year's report [9]. The work presented in this report expands the demonstration of SATS to include testing on irradiated fuel. The completion of an in-cell LOCA test on a high burnup North-Anna M5 fuel rod validates that the system can be successfully used to test commercial fuel.

\subsection{ROD CHARACTERIZATION AND RE-FABRICATION}

The entire irradiated North Anna fuel rod (P16) was characterized extensively before re-fabrication and performing the LOCA test on a fuel segment. The fuel rod was used in a 17x17 Pressurized Water Reactor (PWR) core, and the average burnup of the rod was determined to be $67.3 \mathrm{GWd} / \mathrm{MTU}$ [10]. The axial burnup distribution for the North Anna rod is expected to be very similar to the observed profile for other PWR high burnup fuel rods, which is shown in Figure 10 [11]. The location of the fuel segment used for the LOCA test was within Zone 1, where the grid spacers do not cause a depression of the burnup. Previous characterization of high burnup fuel has indicated the midplane corrosion layer thickness $(\approx 10 \mu \mathrm{m})$, hydrogen content, and fuel morphology to be uniform along all axial locations [12]. Therefore, these values were assumed to be uniform in the North Anna fuel segment used for this LOCA integral test. 


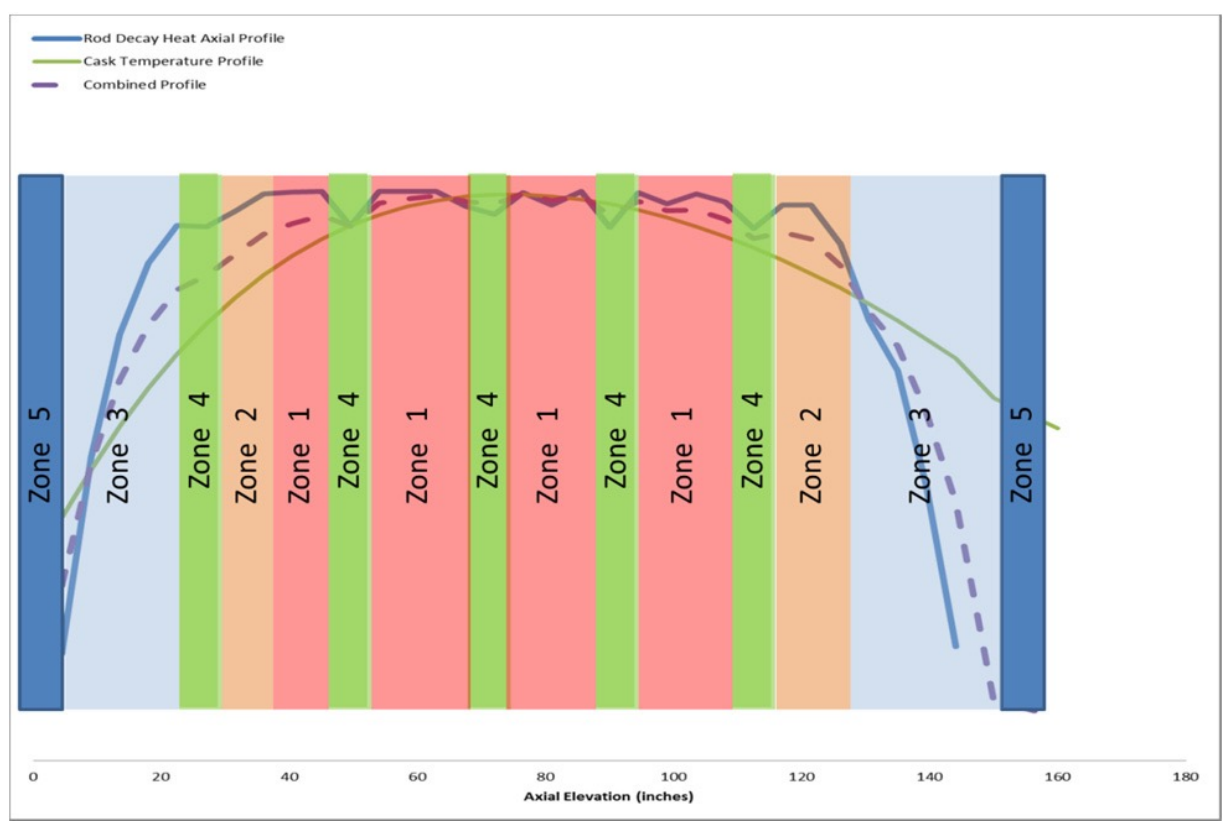

Figure 10. Gamma count on high burnup PWR fuel rod, showing that the burnup is relatively stable between spacers [11].

The North Anna \#1 (NA\#1) fuel segment was prepared by following the re-fabrication process outlined in Sections 3.1-3.6 of this report. However, this fuel segment was not welded at the ends, but was instead sealed by Swagelok prior to testing. Swagelok sealing is an option for accelerated testing and can be used when the rod has the correct dimensions to accommodate the fittings. The schematic of the original North Anna rod with the sectioning plan is shown in Figure 11. Two MET samples and one compression ring test sample were sectioned from the rod before the remaining segment (11.4") was used in the LOCA test. The ring section will be used in a ring compression test to obtain mechanical behavior data for comparison to the LOCA results.

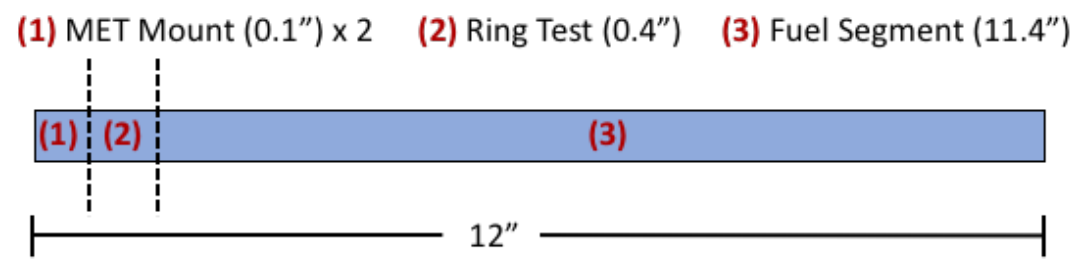

Figure 11. Schematic of a 12" North Anna fuel rod (P16) segment, showing the segment (650D2) that was sectioned and used in the integral LOCA test.

\subsection{INTEGRAL LOCA TEST ON HIGH BURNUP FUEL SEGMENT}

The SATS LOCA test apparatus for this experiment (shown in Figure 12) includes the North Anna segment inside of a quartz tube and a fully instrumented test train. The test train has the capability of measuring the temperature and pressure throughout the experiment. The test was conducted with two Type-S thermocouples strapped to the outer surface of the cladding approximately 2 inches above the 
sample centerline. One of these was used to control the furnace power to give a hold temperature of $1200^{\circ} \mathrm{C}$ at that location. The other thermocouple, located $180^{\circ}$ from the control thermocouple, was used as a backup thermocouple to record temperature in the event that the control thermocouple failed. Based on out-of-cell benchmark testing of unirradiated Zry-2, the difference in output between a strapped and a welded thermocouple at the same axial elevation is $<10^{\circ} \mathrm{C}$. Similar testing of temperature gradients between midplane $180^{\circ}$ apart, and 2 inches above and below midplane were performed showing $<10^{\circ} \mathrm{C}$ variation in temperature [9].

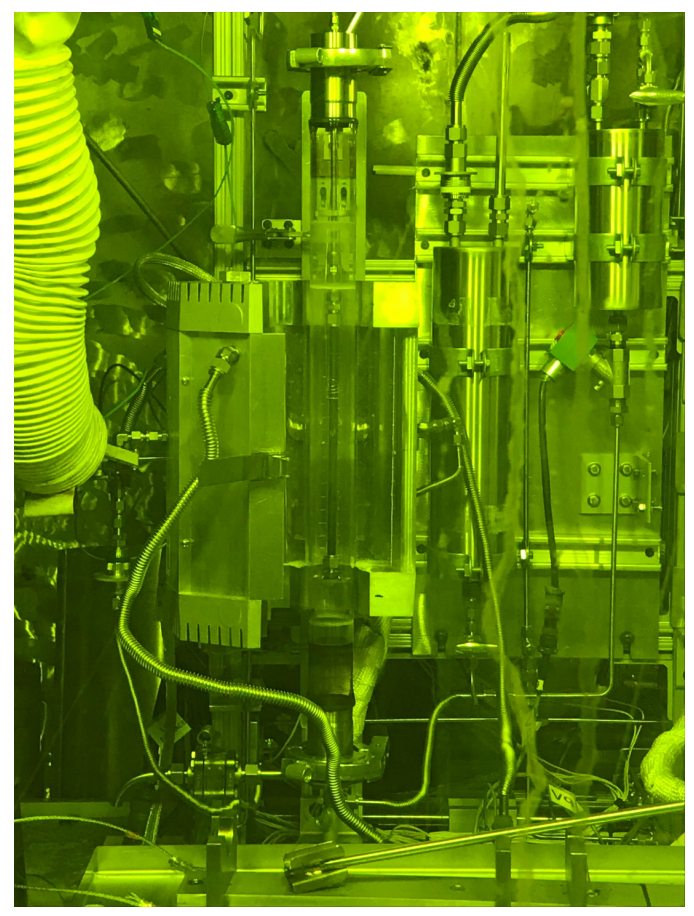

Figure 12. North Anna fuel segment loaded in SATS LOCA test apparatus.

The experiment was conducted as a fully integral test, meaning multiple out-of-cell phenomena expected to occur during a LOCA were simulated. The full LOCA sequence included:

- Heating in flowing steam to $300^{\circ} \mathrm{C}$ and pressurizing fuel segment to $1200 \mathrm{psi}$

- Heating in flowing steam at $5^{\circ} \mathrm{C} / \mathrm{s}$ from $300^{\circ} \mathrm{C}$ to $1200^{\circ} \mathrm{C}$

- Holding in steam for $90 \mathrm{~s}$ at $1200^{\circ} \mathrm{C}$

- Cooling at $3^{\circ} \mathrm{C} / \mathrm{s}$

- $\quad$ Rapid cooling by water quench at $800^{\circ} \mathrm{C}$

Figure 13(a) shows an image taken during the heating step of the test and Figure 13(b) shows an image taken during the water quench. 


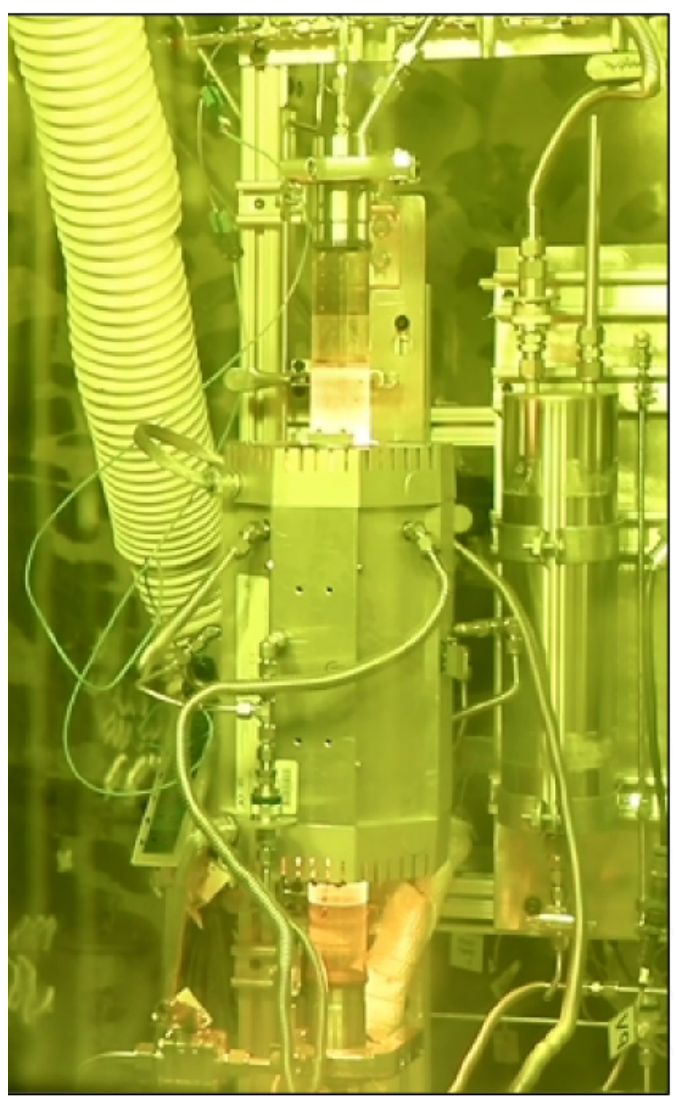

(a)

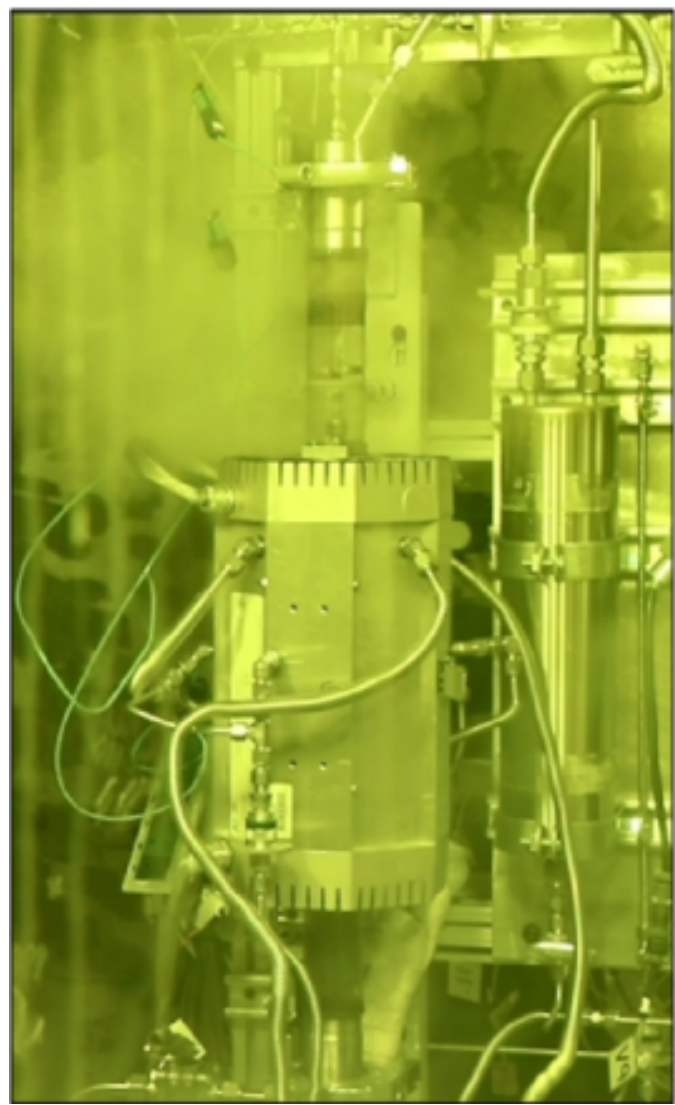

(b)

Figure 13. Photographs taken during the in-cell LOCA test showing (a) the temperature ramp and (b) immediately following the water quench.

\subsection{TEST RESULTS}

The temperature and pressure evolution throughout the entire LOCA test, including the quench, is shown in Figure 14; the trend for each parameter is similar to those seen in previous integral LOCA tests [12]. The results from this experiment were compared to a LOCA test that was conducted at ANL in order to validate the operation and behavior of the SATS system. Table 1 summarizes the results for the ANL integral LOCA test with high-burnup fueled Zr-2 cladding and the current ORNL in-cell test of M5 cladding, referred to as NA\#1. The ORNL in-cell test was run with a full LOCA sequence similar to the test conditions of ANL ICL\#4, except for a shorter hold time. Although the sample size and cladding material are different between the two tests, the burst temperature and pressure of the ORNL NA\#1 test closely follow the ANL ICL\#4 test, which is shown by the similar values for the test results, listed in Table 1. The result of the test was a burst in the cladding and fuel fragmentation, which is pictured in Figure 15. Post-test examinations on the NA\#1 fuel rod segment will be performed to get the strain distribution, burst opening features, degree of fuel fragmentation, and other properties to characterize the LOCA behavior. 


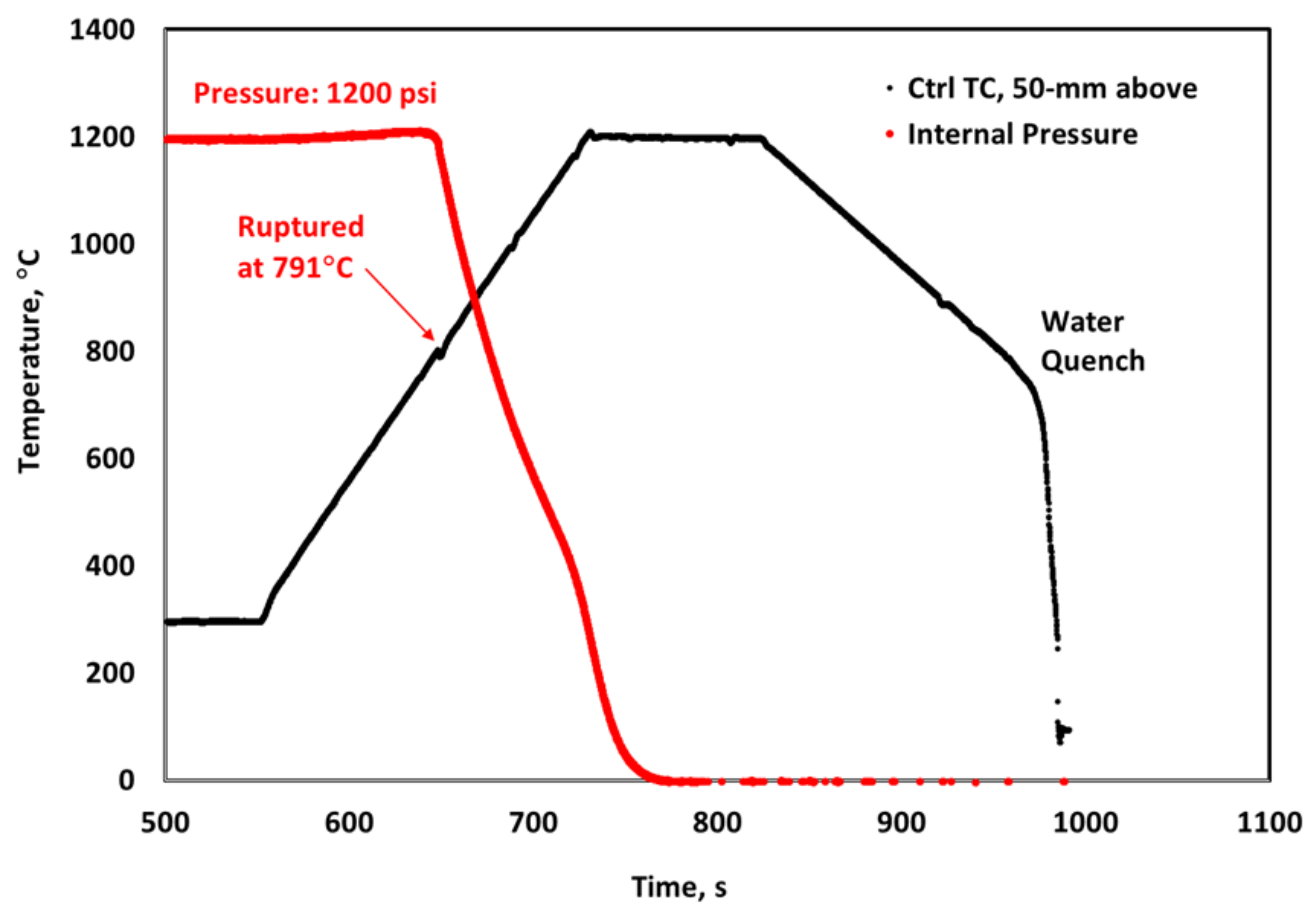

Figure 14. Temperature and pressure histories for the in-cell LOCA test NA\#1 through full LOCA integral test sequence, including water quench at $800^{\circ} \mathrm{C}$.

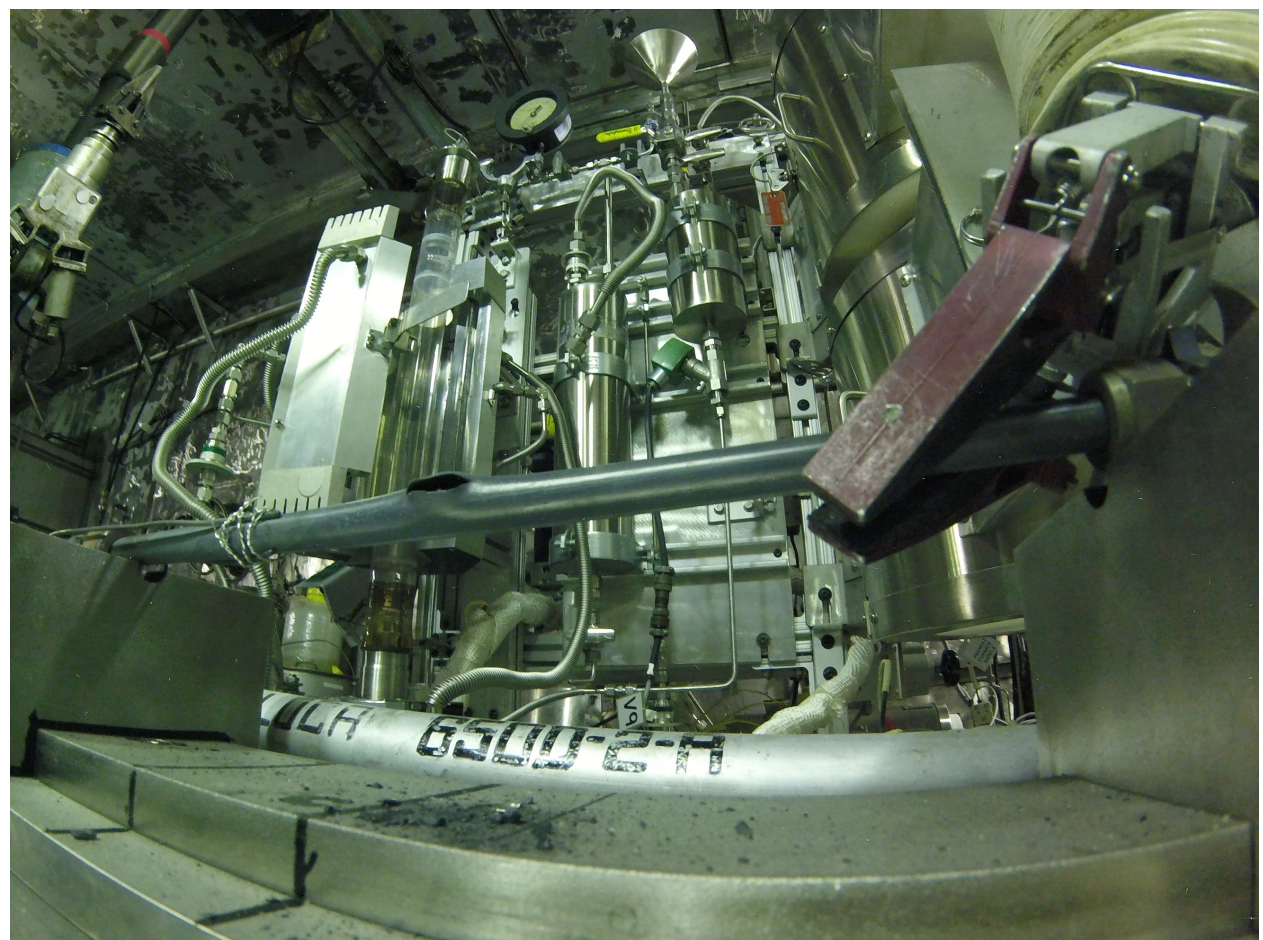

Figure 15. Manipulator holding the burst North Anna \#1 fuel rod segment in front of the SATS system after the completion of an in-cell LOCA test. 
Table 1. Comparison of the ORNL in-cell LOCA integral test on the North Anna fuel segment with a previous test performed at ANL on a high-burnup specimen [12].

\begin{tabular}{|c|c|c|}
\hline Parameter & ANL ICL\#4 & ORNL NA\#1 \\
\hline Fuel & Limerick & North Anna \\
\hline Materials & Zircaloy-2 & M5 \\
\hline Burnup, GWd/MTU & $54-57$ & 67.3 \\
\hline $\mathrm{OD}, \mathrm{mm}$ & 11.18 & 9.50 \\
\hline Wall Thickness, mm & 0.71 & 0.57 \\
\hline Test Environment & Steam & Steam \\
\hline Hold Temperature, ${ }^{\circ} \mathrm{C}$ & 1204 & 1200 \\
\hline Hold Time, s & 300 & 90 \\
\hline Quench Temperature, ${ }^{\circ} \mathrm{C}$ & 800 & 800 \\
\hline Max. Pressure, psi & 1285 & 1214 \\
\hline Burst Pressure, psi & 1160 & 1189 \\
\hline Burst Temperature, ${ }^{\circ} \mathrm{C}$ & $\approx 790$ & $\approx 791$ \\
\hline Burst Shape & Oval & Oval \\
\hline Burst Length $\left(\mathrm{L}_{b}\right), \mathrm{mm}$ & 15 & 16 \\
\hline Max. Burst Width $\left(\mathrm{W}_{\mathrm{b}}\right), \mathrm{mm}$ & 5.1 & 3 \\
\hline Balloon Length $\left(\mathrm{L}_{\mathrm{bal}}\right), \mathrm{mm}$ & $\approx 80$ & $\approx 50$ \\
\hline $\operatorname{Max} \Delta \mathrm{D} / \mathrm{D}_{0}, \%$ & $36 \pm 10$ & $41 \pm 2$ \\
\hline
\end{tabular}

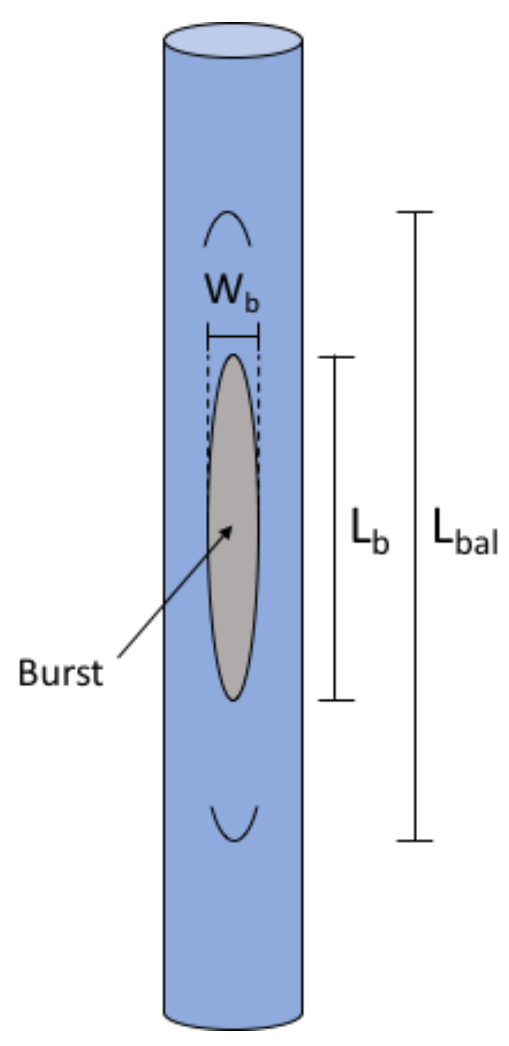




\section{SUMMARY AND FUTURE WORK}

The Severe Accident Test Station was successfully used to test a re-fabricated high burnup commercial fuel segment subject to integral LOCA testing conditions. This validation testing of the SATS system using high burnup fuel demonstrates readiness to perform integral fuel safety testing on a wide range of fuel and cladding concepts. The in-cell re-fabrication capabilities outlined in this report provide flexibility to segment rods, remove fuel and oxide layers, as well as, weld various cladding geometries and materials. In-cell testing can be performed on varying specimen lengths of either fueled or de-fueled segments for DBA and BDBA testing.

The results from all integral LOCA tests, including those that will be performed in the SATS, provide valuable data for code and modeling validation, which enhances the ability to predict behavior of fuel systems during accident scenarios. Experimental data on the performance of high burnup fuel during accident scenarios is especially useful since there is a significant data gap in this subject area [14]. Validation of nuclear fuel performance codes, such as BISON, will provide results that can either act as a screening tool for future experiments or be coupled with experimental data to validate the behavior of a fuel system during safety testing [15].

Future test plans include high temperature oxidation of fueled ATF-1 and ATF-2 rodlets irradiated at the Advanced Test Reactor (ATR) at Idaho National Laboratory (INL), as-fabricated ATF cladding safety testing in support of industry led concepts, and fuel fragmentation testing of high burnup spent fuel benchmarking ahead of similar rodlet ATR irradiations to higher burnup and Transient Reactor Test Facility (TREAT) testing. More detail on the future work can be found in the 2017 report on the SATS hot cell installation [9]. 


\section{REFERENCES}

[1] Domestic licensing of production and utilization facilities, 10 CFR 50.46.

[2] C. Miller, A. Cubbage, D. Dorman, J. Grobe, G. Holahan, N. Sanfilippo, Recommendations for Enhancing Reactor Safety in the $21^{\text {st }}$ Century, United States Nuclear Regulatory Commission (2011).

[3] G. Ledergerber, S. Abolhassani, M. Limback, R Lundmark, K. Magnusson, "Characterization of high burnup fuel for safety related fuel testing," Journal of Nuclear Science and Technology, 43 (2006): 1006-1014.

[4] N. Hollasky et al., Very High Burn-ups in Light Water Reactors, Nuclear Energy Agency, Organization for Economic Co-operation and Development (2006).

[5] K. Pettersson et al., Nuclear Fuel Behaviour in Loss-of-coolant Accident (LOCA) Conditions, Nuclear Energy Agency, Organisation for Economic Co-operation and Development (2009).

[6] M. Flanagan, P. Askeljung, A. Puranen, Post-test Examination Results from Integral, HighBurnup, Fueled LOCA Tests at Studsvik Nuclear Laboratory, US Nuclear Regulatory Commission (2013).

[7] V. Brankov, G. Khvostov, K. Mikityuk, A. Pautz, W. Wiesenack, "Characterization of the relocated and dispersed fuel in the Halden reactor project LOCA tests based on gamma scan data," Nuclear Engineering and Design, 300 (2016): 97-106.

[8] M. Snead, Y. Yan, M. Howell, J. Keiser, and K. Terrani, "Severe Accident Test Station Design Document, Oak Ridge National Laboratory (2015).

[9] K. Linton, Y. Yan, Z. Burns, K. Terrani, Hot Cell Installation and Demonstration of the Severe Accident Test Station, Oak Ridge National Laboratory (2017).

[10] D. Jadernas, K. Yueh, M. Bales, D. Wachs, K. Terrani, K. Linton, N. Meacham, Sample Selection Report for the Irradiation and Post-irradiation Examination of Ultra High Burnup Fuel, Idaho National Laboratory (2018).

[11] J. Scaglione, R. Montgomery, B. Bevard, Post Irradiation Examination Plan for High Burnup Demonstration Project Sister Rods, Oak Ridge National Laboratory (2016).

[12] M. Billon, Y. Yan, T. Burtseva, R. Daum, "Cladding embrittlement during postulated loss-ofcoolant accidents,” ANL00704/NUREG-6967 (2008).

[13] J. Carmack, K. Barrett, H. MacLean-Chichester, Light Water Reactor Accident Tolerant Fuels Irradiation Testing, Top Fuel (2015).

[14] B. Hanson, S. Marschman, M. Billone, J. Scaglione, K. Sorenson, S. Saltzstein, High Burnup Spent Fuel Data Project Sister Rod Test Plan Overview, Pacific Northwest National Laboratory (2016). 
[15] D. Perez, R. Williamson, S. Novascone, G. Pastore, J. Hales, B. Spencer, Assessment of BISON: A Nuclear Fuel Performance Analysis Code, Idaho National Laboratory (2013). 